УДК 159.964.21.5

DOI https://doi.org/10.26661/2310-4368/2020-2-3

\title{
ІНДИВІДУАЛЬНА НЕПОВТОРНІСТЬ СИМВОЛІКИ СНОВИДІНЬ ТА АРХЕТИПНОЇ СИМВОЛІКИ
}

\author{
Дроздова Д. С. \\ кандидат психологічних наук, \\ дочент кафедри психологї \\ Горлівський інститут іноземних мов \\ Донбаського державного педагогічного університету \\ вул. В. Першина, 24, Бахмут, Донецька область, Украӥна \\ orcid.org/0000-0003-1254-0728 \\ diana.drozdova@gmail.com
}

Ключові слова: архетип, сновидіння, індивідуальна неповторність, психомалюнок, свідоме, несвідоме, метод активного

соиіально-психологічного пізнання, протагоніст.
У статті визначено низку науковців, які займалися вивченням сновидінь, архетипної символіки та символів. За допомогою психоаналітичних словників та енциклопедій наведений змістовий складникосновних понять зазначеної проблематики. Особливе значення приділено трактуванню архетипної символіки саме психоаналітиками - 3. Фрейдом та К. Юнгом. Наголошено на механізмах символізації, які були виділені 3. Фрейдом у процесі аналізу сновидінь та уточнені академіком Т.С. Яценко (згущення, зміщення, натяк, локалізація, генералізація, маскування кількістю, від супротивного, гіперболізація, мінімізація, схематизація в контексті психодинамічного розуміння психіки).

Розкрито можливості аналізу психомалюнків за методом активного соціально-психологічного пізнання, зокрема завдяки єдності свідомого та несвідомого компонентів психіки в процесі малювання, веденню діалогічної взаємодії психолога і респондента, спонтанності та невимушеності психокорекційного процесу, універсальності архетипної символіки.

Проаналізовано характерологічні відмінності між сновидінням та психомалюнком, а саме: в роботі з останнім можливо знизити контролюючу функцію свідомості, долучити респондента до процесу активної діяльності, попрацювати з конкретними образами. Образність при цьому визначена i як з’єднуючий компонент символіки сновидінь та психомалюнків.

Подано визначення поняття «архетип» 3 точки зору можливості за допомогою нього пізнавати логічний, індивідуально-неповторний зміст несвідомого респондента 3 метою отримання психокорекційного ефекту. Зазначено, що в процесі групової психокорекції доцільно використовувати аналіз сновидінь разом з іншими психокорекційними методиками. На перший план при цьому виходить професіоналізм психолога, який за допомогою встановлення логічних взаємозв'язків між образами, символами, архетипами та змістом діалогічної взаємодії з респондентом досягає бажаного психоаналітичного результату.

Теоретичний екскурс підтверджено наведенням фрагменту психоаналітичного аналізу снів протагоніста (представлені у малюнках), який брав участь у роботі психокорекційної групи за методом активного соціально-психологічного пізнання. 


\title{
INDIVIDUAL UNIQUENESS OF DREAM SYMBOLS AND ARCHETYPAL SYMBOLISM
}

\author{
Drozdova D. S. \\ Candidate of Psychological Science, \\ Associate Professor at the Department of Psychology \\ Horlivka Institute for Foreign Languages \\ of the Donbas State Pedagogical University \\ V. Pershyna str., 24, Bakhmut, Donetsk region, Ukraine \\ orcid.org/0000-0003-1254-0728 \\ diana.drozdova@gmail.com
}

Key words: archetype, dream, individual uniqueness, psycho-drawing, conscious, unconscious, method of active socio-psychological cognition, protagonist.
The article identifies a number of scholars who have addressed the issue of dreams, archetypal symbolism and symbols. The semantic component of the basic concepts of the specified problem is resulted with the help of psychoanalytic dictionaries and encyclopedias. Special attention is paid to the interpretation of archetypal symbolism by psychoanalysts such as Z. Freud and K. Jung. Emphasis is placed on the mechanisms of symbolization which were identified by Z. Freud in the process of the analysis of dreams and clarified by academician T. Yatsenko (thickening, displacement, hint, localization, generalization, masking by number, by contradiction, hyperbolization, minimization, schematization in the context of psychodynamic understanding of the psyche).

The possibilities of psycho-drawings analyzing by the method of active sociopsychological cognition are revealed in the article, in particular due to the unity of conscious and unconscious components of psyche in the process of drawing, dialogical interaction of a psychologist and a respondent, spontaneity and ease of psycho-correction process, universality of archetypal symbolism.

The characterological differences between the dream and the psycho-drawing are analyzed, namely, in dealing with the latter it is possible to reduce the controlling function of consciousness, to involve the respondent in the process of active activity, to work with specific images. Imagery is also defined as a connecting component of the symbolism of dreams and psycho-drawings.

The definition of the concept of "archetype" in terms of the ability to use it to learn the logical, individually unique content of the unconscious respondent in order to obtain a psycho-correctional effect is submitted. It is noted that in the process of group psycho-correction it is advisable to use the analysis of dreams together with other psycho-correction techniques. The professionalism of a psychologist comes to the fore, who achieves the desired psychoanalytic result by establishing logical relationships between images, symbols, archetypes and the content of dialogic interaction with the respondent.

The theoretical digression is confirmed by a fragment of the psychoanalytic analysis of the dreams of the protagonist (presented in the pictures) who took part in the work of the psycho-correctional group by the method of active sociopsychological cognition.
Постановка проблеми. Проблемою вивчення сновидінь у різних галузях науки займалися Аристотель, А.М. Вейн, Е.С. Доддс, М. Жуве, Л.В. Карасьов, М.В. Ковальзон, С. Лаберж, В.С. Роттенберг, 3. Фред, Е. Фромм, К. Юнг та інші. Поняття «архетип» у науковій літературі знаходить відображення у працях таких учених, як: С. Гроф, Е. Едінгер, Ю.А. Мединська, А. Мене- гетті, Е. Нойман, Дж. Хіллман, Н. Фрай, 3. Фрейд, К. Юнг, Т.С. Яценко та інші. Висвітлення феномена символізації змісту несвідомого було розпочате у психоаналізі (А. Беккер, Е. Гловер, Ж. Лакан, Ч. Музатті, П. Орбан, Ч. Райкрофт, Р. Руссійон, Ф. Тайсон, Р. Тайсон, З. Фрейд та ін.) та філософiї (О.Ф. Лосєв, Н.В. Кулагіна), а продовжено у роботах Ж. Лакана, О.В. Марічевої, П. Орбана, 
Р. Руссійона, Т.С. Яценко та інших. Сьогоднішня наукова думка транслює різні визначення понять «архетип» та «сновидіння» відповідно до підходів та критеріїв тієї галузі, яка досліджує це явище: психологія, культура, реклама, мова та література, мистецтво, історія та ін. Аналіз останніх досліджень сучасних українських учених, таких як: Л.О. Забєліна, С.В. Бичатін, С.А. Маленко, О.С. Колесник, Н.О. Плахотнюк, А.Б. Поцелуйко, Н.В. Зборовська, О.А. Донченко, С.Б. Кримський, В.А. Личковах, Ю.В. Павленко, М.В. Попович, С.В. Більченко, І.Б. Зубавіна, Н.В. Хамітов, Л.В. Дербеньова, В.Г. Даниленко, Л.Б. Тарнашинська, М.Ю. Северинова, А.М. Шестак, А.Е. Нямцу, В.С. Горський та ін., свідчить, що вони у своїх доробках регулярно апелюють до феномена архетипу з різних точок зору наукового пізнання. Виходячи з наявного ступеня розробки заявлених феноменів у психологічному ракурсі, можна заначити, що вивчення змісту індивідуальної наповненості архетипної символіки та символіки сновидів у психокорекційному процесі залишається важливою, актуальною та затребуваною психологічною проблемою (зокрема, у царині психологічного консультування та терапіі), що й визначило вибір теми для наукового дослідження.

Мета статті полягає в розкритті проблеми вивчення індивідуальної неповторності символіки сновидінь та архетипної символіки на матеріалі психоаналітичної роботи з психомалюнком.

Виклад основного матеріалу. Вивченням психологічних значень сновидінь займався австрійський учений 3. Фрейд, який і дав поштовх для появи поняття «архетип». 3. Фрейд, а потім і К. Юнг [3] зазначали, що в снах є основа, тобто вихідна точка процесу вільних асоціацій. К. Юнг зауважував: «З. Фрейд зробив просте, але глибоке спостереження: якщо заохотити того, хто бачив сон, продовжувати розповідь про нього в думках, на які він наводить, то пацієнт піде доволі далеко...» [4, с. 30]. Сон несе у собі певні характеристики суб'єкта, який його бачить, індивідуальні та неповторні змісти його свідомої діяльності, взаємини 3 оточуючим світом та несвідомі змісти психіки.

Під час аналізу сновидінь 3. Фрейдом були відкриті механізми символізації: натяк, згущення, зміщення, образність, вторинна обробка. У наукових дослідженнях Т.С. Яценко уточнено зміст таких механізмів: згущення, зміщення, натяку, локалізації, генералізації, маскуванні кількістю, від супротивного, гіперболізації, мінімізації, схематизації в контексті психодинамічного розуміння психіки.

Як зазначено в психологічній енциклопедії, «архетип» (грец. archetypos - первообраз, найдавніший зразок) - спосіб поєднання образів, символів, знаків за допомогою форм, які передаються із покоління в покоління» [2, с. 31]. «Архетип» - не новий термін, його використовували задовго до св. Августина як синонім до класичного поняття «ідея» [5, с. 209]. Архетипна символіка - це символіка, яка виражає зміст колективного несвідомого, що значною мірою має спільні характеристики для всього людства, але набуває індивідуального значення в конкретних виявах активності суб'єкта. Щоразу символи наповнюються додатковим значенням залежно від індивідуального досвіду суб'єкта [6, с. 138].

Аналіз психомалюнків за методом активного соціально-психологічного пізнання (АСПП), що було розроблено Т.С. Яценко, підтвердив важливу роль архетипів у виявленні певних аналогій і характеристик психіки суб'єкта. Архетип є вродженим інстинктом, що забезпечує образну передачу змісту за допомогою символів, які мають причетність до колективного несвідомого. Архетипна символіка відзначається архаїчним характером, відображає індивідуально-неповторний досвід суб'єкта, актуалізується за умов виникнення опорів, коли зміст несвідомого не можна пізнати. Саме архетипи поєднують сновидіння 3 психомалюнком. Аналітик у роботі зі сновидінням тримається ближче до змісту сну, а в діалозі 3 автором малюнка ми намагаємось не відходити від його малюнка [7]. Спонтанність та невимушеність у процесі виконання малюнка за методом АСПП єднає його з методом вільних асоціацій 3. Фрейда. Визначення тем малюнків демонструє єднання свідомої сфери психіки з несвідомою, що проявляється в процесі малювання.

T.С. Яценко вважає, що малюнок та сновидіння відрізняються характером виникнення та внеском свідомого й несвідомого у зміст зображення. Процес сновидіння включає участь свідомості, в роботі з малюнками ми намагаємось знизити іiі контролюючу функцію. Сновидіння ніби підносить людину над повсякденністю, створюючи малюнки, людина одночасно знаходиться в самому процесі. Іще одна відмінність між сновидіннями та психомалюнками полягає в тому, що у сновидіннях увесь матеріал підлягає процесові відтворення, згадування. Водночас їх єднає образність. У психомалюнку образи домінують над поняттями. «Кожний із нас сприймає абстрактні й загальні положення по-своєму. Причиною цього може бути те, що будь-яке поняття має власне забарвлення в особистому контексті, тому й індивідуально неповторне», - зазначає автор [8, c. 119].

У практиці роботи груп активного соціально-психологічного пізнання немає окремого методу роботи зі снами, але є спільне в роботі із символікою малюнків та сновидінь. Групова 
психокорекція може актуалізувати виникнення у протагоніста спогади про певне сновидіння. На перший план виходить професіоналізм психолога, завдяки якому він зможе виявити оригінальність конкретизації та індивідуалізації змісту архетипу в кожному випадку шляхом встановлення логічних взаємозв'язків між образами, символами та змістом діалогічної взаємодії з автором малюнка. Тому аналіз сновидінь доцільно проводити разом 3 іншими психокорекційними методиками.

Таким чином, у сновидіннях закладений індивідуальний досвід психіки особистості, який інтегрується 3 проблемами інфантильного порядку. Завдяки архетипам, які презентують у снах актуальні для протагоніста образи, можна психологічно інтерпретувати їх у процесі діалогу з респондентом.

Архетипи розкриваються лише за допомогою символічних образів, що постають в уяві та мають відображення у малюнках. Усе це засвідчує, що під поняттям «архетип» слід розуміти не лише здатність психіки передавати зміст в образах, а й можливість пізнавати логічний зміст несвідомого. Наявні у малюнках архетипи насичені індивідуальним змістом протагоніста.

Для практичної ілюстрації вищезазначеного наведемо фрагмент аналізу снів протагоніста $A .$, які вона зобразила у вигляді власних малюнків. Робота проводилась у малій психокорекційній групі (10-15 осіб, їх орієнтовна тривалість становить 100-120 годин, по 8 годин на добу) за методом АСПП під керівництвом академіка Т.С. Яценко. Функційна специфіка несвідомого зумовлює підбір методик, які б дозволили пізнавати психічне в цілісності, контекстно й опосередковано. Багаторічна практика психодинамічного підходу переконує, що психіка архетипно здатна до візуалізації у разі перекодування в матеріалізовані форми (наприклад, малюнки). 3 огляду на те, що психіка формується ще в домовний період, включаючи перинатальний, важливим є використання візуалізованих моделей, які відтворюють невербальний досвід. Індивідуалізоване пізнання можливе за рахунок спонтанної поведінки учасників групи. Цінність АСПП полягає в його зорієнтованості на індивідуальну неповторність психіки суб'єкта. Врахування вищесказаного є однією $з$ передумов, яка забезпечує можливість проникнення у «скрите», спираючись на образ, який $є$ основою мови несвідомого, на відміну від свідомого, в якому пріоритет має слово. Для точності діагностико-корекційного процесу також необхідно враховувати голографічну природу психічного, що становить дискретність, і навпаки, часово-просторові параметри психіки та здатність до диференціювання [1].
Психоаналіз малюнків снів протагоніста $A$.

А.: Я намалювала свої сни.

П.: Якщо забути, що це сон, то як би ви його назвали? Що тут намальовано? Який малюнок вам найближчий?

А.: «Небезпека» - найцікавіший, дивний (див. рис. 1).

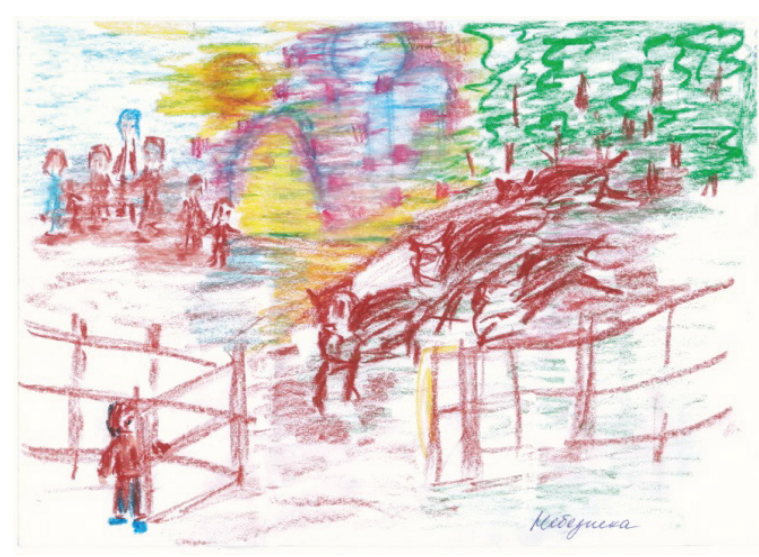

Рис. 1. «Небезпека»

П.: Будь ласка, розкажіть у чому його дивність?

А.: Цей сон про те, як я попадаю в середовище інших людей - євреїв, у них свято, і відбувається ритуальне дійство. K-m 1 (комунікат 1). Це - храм, там проходила служба i мене туди запросили. $K-m 2$. Але я туди не пішла, тому що там розмовляли іншою мовою. $K-m$ 2. Мені дуже хотілось, але я відмовилась, тому що знала, що емоційно та інформативно мене це не зацікавить.

П.: А це ви за тином?

А.: Так. Переді мною порожнеча, а далі ліс, 3 якого вибігали дикі тварини. Вони пробігали повз людей і мали не зачепити людей біля храму. Це свідчило про те, що вони завжди в безпеці. У цьому сні мені десять років. $K-m$ 3. Я сховалась за тином від тих тварин, хоч цей тин і не такий надійний. Всі вони побігли у напрямку воріт. Інші люди просто дивились, а я одна. $K-m$ 3. Тварини зачепили ворота, але я не постраждала. Мені було страшно, але я не пішла звідси, хоч і не розумію чому. Всі давно порозбігались, а я все ще залишаюсь на місці. Мені було страшно піти і страшно залишитись. Я прокинулась тільки тоді, коли 3 лісу почали вибігати зубри.

П.: А як пов’ язані з тваринами євреї, які зображені на малюнку?

А.: Ці тварини наче з їхнього світу, а я прийшла на екскурсію. Мені хотілося бути просто спостерігачем, але не вийшло через тварин.

П.: Цей храм намальований так, як малюють образи людей. Ми бачимо голову, тіло.

А.: Так. 
П.: А чи є у вас знайомі з цієї спільноти?

А.: $€$, але я з ними не спілкуюся.

Інтерпретаиія психолога. Цей малюнок (див. рис. 1) може говорити про ваш переїзд, про те, що ви стикаєтесь з різними людьми, з їхніми правилами, до яких треба якось прилаштовуватись $(\kappa-m l)$. Ви тільки заглянули до храму, а вас уже щось дуже бентежить ( $\kappa-m$ 2). Зображення входу у храм свідчить про зв'язок із матір'ю $(\kappa-m l)$, наче вам не вистачає близькості $з$ матір'ю. Вам хочеться увійти до храму, але щось зупиняє $(\kappa-m$ 2). Це $\epsilon$ проявом тривоги. Стадо звірів вас лякає, але ви знаєте, що це повинно відбутися, i тому відбуваються такі алогічності. Але навіть якщо звірі підійдуть, то все одно ви самозбережені ( $\kappa-m 3)$. I це дуже цікаво. Звертає увагу жовтий колір. Цим кольором ви промалювали і храм, і огорожу, це пов'язано з жіночністю. Варто помітити, що ви ховаєтесь за тином навіть тоді, коли він відкрився (к-m 3), і не зможе захистити.

А.: У мене схожі відчуття. Дуже достовірна інформація.

П.: Наступний малюнок «Пошук друга» (див. рис. 2).

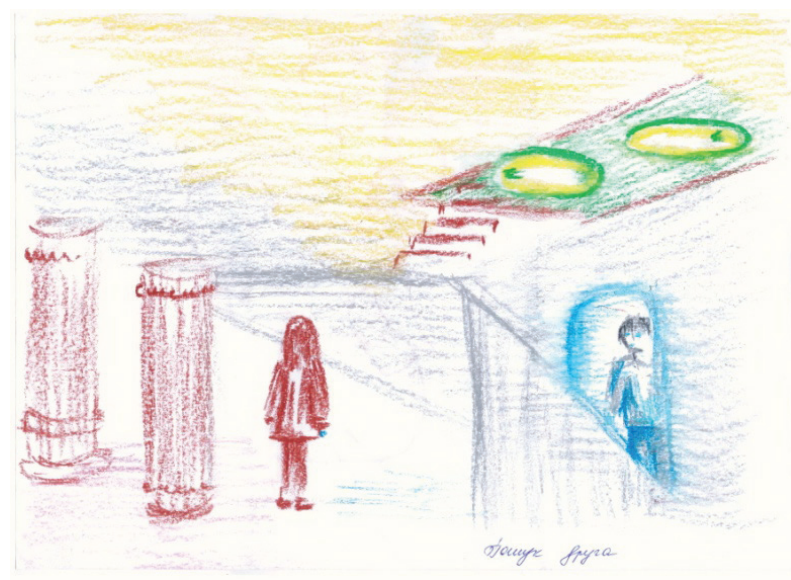

Рис. 2. «Пошук друга»

А.: Будівля 3 колонами. I в цій будівлі я намагаюся знайти людину, яка для мене була значущу. Ї̈̈ всі шукають. Я потрапляю в коридор, який поступово звужується настільки, що мені доводиться повзти. Доповзаючи до кінця, я через щілину бачу двері і іiі. Я можу пролізти через цей вузький прохід, але мені страшно там застрягти. Через це я повертаюся назад і починаю шукати якийсь інший шлях. Знаходжу іншу дорогу у вигляді отворів, і мої друзі теж хочуть так піти. $K-m$ 4. Але там певні труднощі, в цих отворах вода, в якій можна потонути, якщо злякатися. $K-m 5$. Тому я вирішила повернутися до вузького проходу. Я бродила по лабіринту, не могла знайти дорогу. Було жахливо йти до тих виходів, які я знайшла раніше. $K-m 5$. У результаті ми не зустрілися. Було образливо, тому що я відчувала, що це важливо.

Інтерпретація психолога: Сходи - це символ сексуальності. У цьому малюнку зроблено акцент на символі утроби, на відміну від попереднього малюнка, де акцент був на енергетичному натиску. Людина, яку ви шукаєте, зображена у воді, і в отворах теж вода ( $\kappa-m$ 4). Звертає увагу те, що ви шукаєте партнера, який буде подібний батькові. Тільки в утробі ви знаходите з ним так зване «єднання» (к-m 5). I більше ніде. Натяк у цьому малюнку демонструють два отвори, які не можуть з'єднатися, іншими словами: «Я не можу знайти батька». Це не плотський контакт, це тільки друг, тобто платонічний аспект відносин.

Ви зображені біля двох колон. Це натяк на те, що в житті вам дуже важливо мати значущу людину поряд із собою. Вона реалізується через втілення батька в інших, оточуючих вас людей та відчутті його у собі (тому колони дві).

А.: Цей чоловік, якого я шукала, дуже значущий для мене і схожий на батька. До сьогодні я не розуміла, чому у мене з партнером не було сексуального потягу, пристрасті. Виявляється, це через те, що батько табуйований об' єкт на несвідомому piвні.

П.: Ви були готові стрибнути, але все таки вам було важко.

А.: Так.

П.: Наступний малюнок «Дивні події» (див. рис. 3).

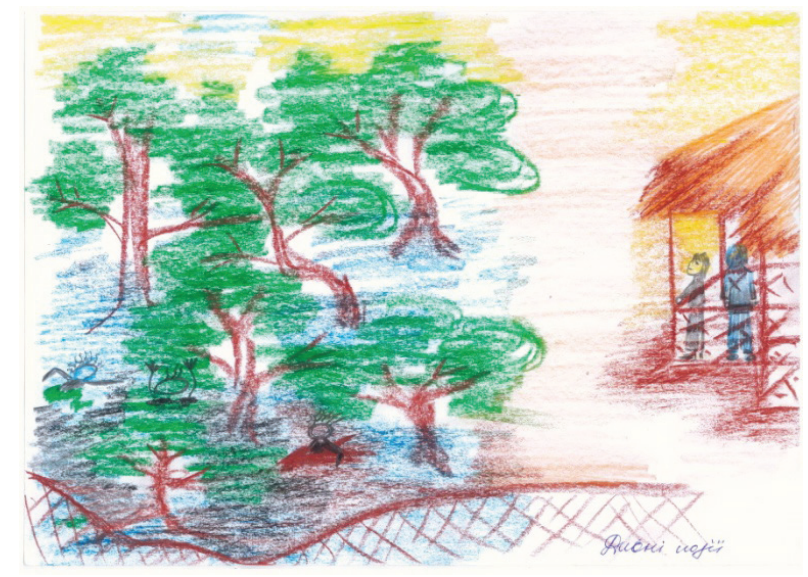

Рис. 3. «Дивні події»

А.: Цей сон розділився на дві серії. Мені снилося штормове море. Я стояла на обриві, було жахливо спуститися до низу. $K-m 6$. У другій серії я йшла уздовж моря, але тепер на обриві з'явилася сітка, хоча і не надійна. $K-m$ 6. Я боялась, що підійду до цієї сітки і впаду в море разом з нею. $K-m 6$. Потім 
я підійшла до лісу, який втоплений у воді. $K-m 7$. Я хотіла цей ліс пройти, але почала тонути в болоті. Інші люди теж там тонули. $K-m$ 7. Я зачепилася за колоду і врятувалась. А люди потонули, допомогти я їм не змогла. Світла практично не було. Я на колоді переплила болото і потрапила в чисту морську воду. Мені там добре, і я залишилась поплавати. В морі я відмилася від болотяного бруду, як і інші люди. Коли я вийшла на берег, то переді мною з'явились піски і бархани. $K-m$ 8. На березі було бунгало, але воно не надійне. $K-m 8$. У цьому будинку жили двоє чоловіків: молодий і старий. Молодий романтик, а старий - дивиться на речі більш приземлено. Вони для мене значущі, ми живемо всі разом. $K-m$ 9. Після ми розходимося, кожний у своєму напрямі. Вони зникають. У мене залишається добре враження.

Інтерпретація психолога: У цьому малюнку (див. рис. 3) акцент ставиться на відчуженні жіночого початку у матері ( $\kappa-m$ б). I якщо це так, то значить ви 3 недовірою ставитеся до власних переваг $(\kappa-m 7)$. Можливо, ви боїтеся розчарування. Що стосується бунгало, то тут натяк на те, що у вас були різні чоловіки $(\kappa-m ~ 8)$. Але до остаточного вибору ви прийти не можете $(\kappa-m 8)$. Ви весь час чекаєте, що вони зникнуть $(\kappa-m 9)$.

А.: У мене постійно страх, що відносини закінчаться. I ще боюся бути не вартою чоловіка.

П.: Страх, що вас залишать. А з менш гідними чоловіками ви бути не хочете.

А.: Так, тому що я буду висувати їм претензії.

П.: Тоді і сидите тільки у болоті $(\kappa-m 7)$, тому що на малюнку вас більше ніде немає.

А.: Я повністю у сумнівах.

П.: Що це за малюнок? (див. рис. 4)

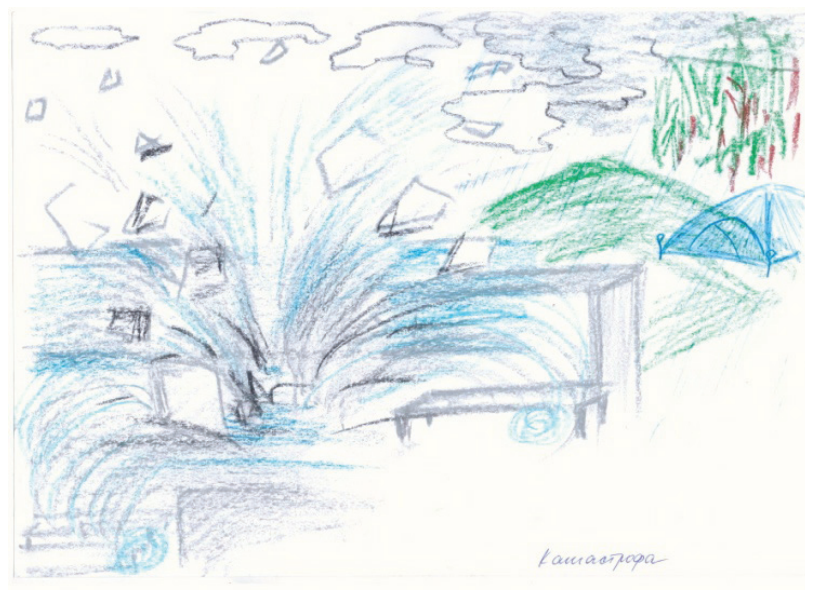

Рис. 4. «Катастрофа»

А.: K-m 10. Це болотиста долина, в якій ми вирішили поставити намет. Десь там є ліс.

Інтерпретація психолога: Ми бачимо тут (див. рис. 4) певне дистанціювання від матері: «що би я не побудувала, вона зруйнує все» (к-m 10).
А.: Зі сторони матері відбувається постійне знецінення.

П.: Якщо в дитинстві вам цього було досить, то чому подібне відчуття наче слідує за вами? Це свідчить про залежність від матері. Можливо, що подібну критичність ви транслюєте і у своїй поведінці.

А.: Так. Відчуття таке, що я постійно вибираю сварки. $K-m$ 11. Уві сні я йду по набережній, і в цей час там трапляється вибух - вибиває частину мосту. Вода 3 величезною силою починає кидати мене і моїх подружок з однієї сторони в іншу то під лавку, то на сходинки. Я тільки встигала набрати повітря.

П.: I знову ми бачимо на малюнку сходинки. Це свідчить про плотський аспект, неначе ви боїтеся плотського натиску з боку чоловіка (к-m 11$)$. 3 одного боку, він і бажаний, а з іншого - ви втрачаєте себе.

А.: Я хочу постійно контролювати ситуацію.

П.: Ви намагаєтесь охороняти свою гідність?

А.: Мені важливо тримати контроль над ситуацією.

П.: Ви вимушені себе пригальмовувати, імпотувати. А коли ви себе імпотуєте, то «вкриваєтеся болотяною травою».

А.: Так, якщо я чогось досягаю, то відразу роблю крок назад.

П.: А хто на вас впливає найбільше?

А.: Тато дуже авторитетний для мене, а маму я намагаюся охороняти.

П.: Ви шукаєте в партнері заміщення матері. Неначе вам самій треба народити чоловіка.

А.: У партнері я шукаю образ батька, а знаходжу маму - дбайливу, ніжну, терплячу.

П.: Це може означати, що вам вистачає турботи, ніжності з боку мами. Якщо розглядати малюнок «Катастрофа», можна припустити, що якщо вам близький подібний гештальт, то ви самі можете ставати «вулканом».

За архетипною симолікою вулкан - чоловіча енергія. Відбувається натяк на те, що ви показуєте чоловіку яким треба бути.

А.: Хочеться, щоб людина почувалася добре поряд зі мною, розвивалася, а виходить навпаки.

П.: Ви і сама не реалізовуєте свій потенціал.

А.: Навіть більше, я сама уникаю можливості самореалізації.

П.: Відповідно, можна говорити про відчуття потенції як енергетичної, так і інтелектуальної. Ще ви обтяжені відчуттям неповноцінності. На це указують ваші малюнки. Наче «ножиці», які урізують ваш потенціал.

А.: Дякую вам. На багато речей я взагалі не звернула увагу, наприклад, на жовтий колір.

П.: Може, його уві сні і не було.

А.: Так. Тепер мені зрозуміло, чому у мене не було близькості 3 хлопцем. Він пропонував мені 
створити свою сім'ю, але я відмовилася, тому що $\epsilon$ незавершені справи у відносинах 3 батьками. Мені постійно необхідно доводити матері, що я краща, а батькові, що я для нього найголовніша.

П.: Тоді це вічна конкуренція, бо мати ще до вашого народження стала головною для батька.

А.: До речі, тато ставиться до мене як до молодшої дружини.

П.: Ваше головне завдання - справлятися 3 натиском енергії, інакше страждатимуть батьки. За малюнками ми прослідковуємо подвійність. Тому ви шукаєте в партнерах як фундаментальність, прагматичність, постійність, так і романтичність, ніжність, турботливість.

Висновки. Таким чином, проведений психоаналіз стенограми психоаналітичної роботи 3 малюнками снів протагоніста А. дає змогу об'єктивувати вияв архетипної символіки у сновидіннях та сприяє вивченню індивідуальних особливостей особистості, прояву іiі глибинної проблематики. Завдяки архетипам, які презентують у снах актуальні для протагоніста образи, можна психологічно інтерпретувати їх у процесі діалогу 3 респондентом. Об'єктивування внутрішнього змісту психіки через архетипну символіку несе як психодіагностичний, так і психотерапевтичний вплив на суб' єкта процесу, надаючи йому можливість вибудовувати продуктивні взаємини з оточуючими, знімати напругу у процесі самореалізаціі, позитивно формувати самосприйняття, реалізувати власний професійний та творчий потенціал.

Використання різних форм та засобів психокорекційної роботи розширює доказовий потенціал роботи із символами та архетипами сновидінь, у чому і вбачаємо перспективи подальших досліджень у заданому напрямі.

\section{ЛITЕРАТУРА}

1. Теория и практика глубинной психокоррекции : Седьмая Авторская школа академика НАПН Украины Т.С. Яценко / сост.: В.П. Андрущенко, А.В. Глузман. Киев : Изд-во НПУ имени М.П. Драгоманова, 2013. $236 \mathrm{c.}$

2. Философский энциклопедический словарь / за ред.: Л.Ф. Ильичев, П.Н. Федосеев, С.М. Ковалев, В.Г. Панов. Москва : Сов. энциклопедия, 1983. 840 с.

3. Юнг К.Г. Алхимия снов. Четыре архетипа. Мать. Дух. Трикстер. Перерождение / пер., авт. послесл. Семира. Санкт-Петербург : Тимошка, 1997. 352 с.

4. Юнг К.Г. Архетип и символ. Санкт-Петербург, 1991. 165 с.

5. Юнг К.Г. Душа и миф. Шесть архетипов. Минск : Харвест, 2004. 400 с.

6. Яценко Т.С. Особливості внутрішньої динаміки психіки. Освіта: педагогіка і психологія. Польсько-український журнал. 2003. № 4. С. 137- 152.

7. Яценко Т.С. Пізнання індивідуальної неповторності архетипної символіки у процесі глибинної корекції. Психологія і освіта. 2013. № 1 (51). С. 75-85.

8. Яценко Т.С. Психологічні основи групової психокорекції : навчальний посібник. Київ : Либідь, 1996. $264 \mathrm{c}$.

\section{REFERENCES}

1. Teoryia y praktyka hlubynnoi psykhokorrektsyy : Sedmaia Avtorskaia shkola akademyka NAPN Ukraynu T.S. Yatsenko. (2013). [Theory and practice of deep psychocorrection] / sost.: V.P. Andrushchenko., A.V. Hluzman. Kyiv : Yzd-vo NPU ymeny M.P. Drahomanova [in Russian].

2. Filosofskij jenciklopedicheskij slovar'. (1983). [Encyclopedic Dictionary of Philosophy] / Za red.: L.F. Il'ichev, P.N. Fedoseev, S.M. Kovalev, V.G. Panov. Moskva : Sov. Jenciklopedija [in Russian].

3. Yunh, K.H. (1997). Alkhymyia snov. Cheture arkhetypa. Mat. Dukh. Trykster. Pererozhdenye [Alchemy of dreams. Four archetypes. Mother. Spirit. Trickster. Rebirth] / per., avt. poslesl. Semyra. Sankt-Peterburg: Tymoshka [in Russian].

4. Jung, K.G. (1991). Arhetip i simvol [Archetype and Symbol]. Sankt-Peterburg [in Russian]

5. Jung, K.G. (2004) Dusha i mif. Shest' arhetipov [Soul and Myth. Six Archetypes]. Minsk: Harvest [in Russian].

6. Yatsenko, T.S. (2003). Osoblyvosti vnutrishnoi dynamiky psykhiky [Features of the Internal Dynamics of the Psyche]. Osvita: pedahohika i psykholohiia. Polsko-ukrainskyi zhurnal. No. 4. S. 137-152 [in Ukrainian].

7. Yatsenko, T.S. (2013). Piznannia indyvidualnoi nepovtornosti arkhetypnoi symvoliky u protsesi hlybynnoi korektsii [Cognition of individual uniqueness of archetypal symbolism in the process of deep correction]. Psykholohiia i osvita. No. 1 (51). S. 75-85 [in Ukrainian].

8. Yatsenko, T.S. (1996). Psykholohichni osnovy hrupovoi psykhokorektsii: navchalniy posibnyk [Psychological Foundation of Group Psycho-Correction: a textbook]. Kyiv: Lybid [in Ukrainian]. 